ki beleži največ leksemov (254) od tukaj zbranih (414).

Primerjava narečnega gradiva $\mathrm{z}$ istovrstnim besedjem $\mathrm{v}$ sosednjem panonskem prleškem in prekmurskem narečju, $\mathrm{s}$ čimer je omogočen vpogled $v$ njihovo razširjenost $\mathrm{v}$ panonskem narečnem prostoru in opozorjeno na morebitne pomenske razlike med obravnavanimi narečji, kaže, da je v monografiji zbrana panonska leksika dokaj pestra, pestrost zapisanih poimenovanj pa povečujeta še njihova izgovorna raznolikost ter tu in tam oblikovna neenotnost, a dovolj enotna za možnost izrisa posameznih arealov, ki jih tvorijo leksemi. Avtorica svoje delo zaključuje z ugotovitvijo, da narečno slovenskogoriško besedje, ki poimenuje slovensko kmečko hišo, prostore in opremo v njej, gospodarska poslopja in kmečko dvorišče, kmečka opravila in orodje, pri srednji in mlajši generaciji govorcev hitro tone $\mathrm{v}$ pozabo, in z željo, da naj njegova predstavitev predstavlja droben, a pomemben prispevek $\mathrm{k}$ ohranjanju slovenske jezikovne kulturne dediščine.

Monografija, za katero je značilno umirjeno in trezno razmišljanje ter sistematično poglabljanje $\mathrm{v}$ jezikoslovno misel, je zahtevno delo, ki pomeni pomembno obogatitev slovenskega jezikoslovja in predstavlja dragocen prispevek v zakladnico narečjeslovnega vedenja.

\section{Marko Jesenšek}

Filozofska fakulteta Univerze v Mariboru marko.jesensek@um.si
SIMONA PULKO IN MELITA ZEMLJAK JONTES: SLOVENSKO ALI KNJIŽNO - KAKO JE PRAV? Maribor: Aristej, Slavistično društvo Maribor, 2015. 152 str.

Humanistična in družboslovna zbirka Dialogi založbe Aristej je bogatejša za znanstveno monografijo dr. Simone Pulko, jezikoslovke, docentke za didaktiko slovenskega jezika in književnosti, in dr. Melite Zemljak Jontes, jezikoslovke dialektologinje, izredne profesorice za slovenski jezik. Soizdajatelj je Slavistično društvo Maribor, katerega članici sta avtorici. Obe sta predavateljici na Oddelku za slovanske jezike in književnosti na Filozofski fakulteti Univerze v Mariboru. Monografija prinaša sodobne ugotovitve s področja jezikoslovja na osi med knjižnim in neknjižnim pri jezikovni rabi mladostnikov.

Naslov Slovensko ali knjižno - kako je prav? provokativno nagovarja bralca, saj današnji odnos do slovenskega jezika (ne le kot materinščine) mnogokrat pušča vnemar tako slovensko kot knjižno. Odnos govorcev do jezika se spreminja, prav tako jezikoslovcev, ki ugotavljajo, da se negativna konotacija, vezana na neknjižni jezik, v zadnjih dvajsetih letih spreminja. V ospredje - v različnih sporazumevalnih okoliščinah in govornih položajih - stopajo neknjižne zvrsti, dvigujejo se na raven, enakovredno knjižnemu jeziku. Monografija prinaša ugotovitve skoraj desetletnega dela (od 2007), in sicer predstavlja presek narečjeslovnih raziskovanj in pregleda didaktičnih vidikov poučevanja jezika v različnih programih državnega institucionalnega izobraževanja. Avtorici sta predstavili, kot tudi v Uvodu navajata sami, narečje kot izhodišče govornega in pisnega (po)ustvarjanja mladostnikov, pri čemer sta za analizo 
izbrali skupino mladostnikov, starih od 12 do 24 let, ki v klasičnih dialektoloških študijah (načeloma) niso informatorji, in analizirali njihov odnos do neknjižnega $\mathrm{v}$ jeziku.

Monografija obsega 152 strani, iz kazala pa lahko razberemo natančno členjenost gradiva, in sicer: Uvod, ki mu sledita dve osrednji poglavji, (1) Teoretični del in (2) Empirični del, monografijo zaključuje za znanstveno monografijo zahtevan instrumentarij: Sklep, Summary (povzetek v angleškem jeziku), Viri in literatura, Stvarno kazalo, Imensko kazalo in Priloga (Vprašalnik za učence/dijake).

Teoretični del prinaša na 38 straneh tri podpoglavja. V prvem, tj. Socialnozvrstna razmerja $v$ sistemu slovenskega jezika, avtorici podajata (1) vpogled v socialne zvrsti slovenskega jezika, glede na literaturo prikažeta vzroke za tako številčno narečno členjenost slovenskega jezika in (2) pojasnjujeta temeljne pojme iz dialektologije, (3) podrobneje se ustavita ob terminu sleng (podani so številni viri, ki raziskujejo to socialno podzvrst slovenskega (neknjižnega) jezika), (4) podrobno predstavita aktualno jezikovno terminologijo - jezikovna norma, normativnost, normativistika, normativna oznaka, standardni jezik, kulturni jezik itd., (5) skleneta s spremembami socialnozvrstnih razmerij $\mathrm{v}$ slovenskem jezikovnem prostoru in opozarjata na različne jezikoslovce ter njihove delitve posameznih jezikovnih različkov na zemljepisna in socialna narečja. Drugo podpoglavje, tj. Socialnozvrstna razmerja $v$ šolskem sistemu, prinaša osvetlitev obravnavane tematike v učnih načrtih in učbeniških gradivih. Najprej so glede na obravnavanje socialne zvrstnosti slovenskega jezika podani pregledi učnih načrtov za osnovno šolo in gimnazije. Sledi podroben prikaz obravnave socialne zvrstnosti slovenskega jezika v naslednjih učbeniških gradivih za (a) osnovno šolo: Slovenščina za vsak dan 7, 8, 9; Od glasov do knjižnih svetov 7, 8, 9; Slovenščina 7, 8, 9; in za (b) srednjo šolo: Na pragu besedila 1, 2, 3, 4. Tretje podpoglavje, tj. Osebna identiteta $v$ rabi socialnih zvrsti slovenskega jezika, se osredinja na jezik in identiteto $\mathrm{v}$ šolskem sistemu.

Empirični del je najobsežnejši (79 strani) in v prvem podpoglavju, Raziskave socialnozvrstnega stanja med mladostniki v Sloveniji, avtorici predstavita štiri sklope raziskav, v katerih sta obravnavali to tematiko: raba zemljepisnih različkov glede na stopnjo izobraževanja in različne govorne položaje, narečje kot izhodišče govornega in pisnega (po)ustvarjanja mladostnikov, narečno $v$ izbranih umetnostnih besedilih slovenskih avtorjev za (mlade) bralce in (ne)moč narečne besede. V drugem podpoglavju, Nadaljnje raziskave socialnozvrstnega stanja med mladostniki $v$ Sloveniji, avtorici podkrepita lastne raziskave $\mathrm{z}$ ugotovitvami nadaljnjih raziskav študentov v letih 2009-2013. Avtorici sta namreč razvili temeljni predmet raziskave, njen namen in raziskovalna vprašanja, ki sta jih sami tudi preizkusili in ki so uspešno prestala sondažo, zato so lahko študentje vsaj v temelju delali z že standardiziranim anketnim vprašalnikom. V izhodiščni raziskavi sta avtorici zastavili temeljne raziskovalne hipoteze, ki so bile v nadaljnjih raziskavah študentov deloma tudi povzemane, kot temeljne pa so bile zastavljene tudi $\mathrm{v}$ sami monografiji. Raziskovalni vzorec je (skupaj) zajel kar 11 osnovnih šol (997 učencev zadnjega triletja), in sicer glede na narečna območja jih pet spada $\mathrm{v}$ panonsko narečno skupino, tri $\mathrm{v}$ štajersko, dve $\mathrm{v}$ dolenjsko in ena $\mathrm{v}$ 
koroško narečno skupino. Zajema torej tudi vzorec diplomskih del, pri čemer pa je treba poudariti, da sta avtorici rezultate posameznih raziskav po šolah združevali in jih tudi na novo analizirali ter interpretirali $\mathrm{v}$ širšo celoto.

Kot predmet raziskave sta opredelili rabo narečij med učenci zadnjega triletja, namen pa je bil na podlagi anketnega vprašalnika, ki temelji na tezi, da je materni jezik vsakega posameznika narečje, pridobiti odgovore na raziskovalna vprašanja, kot so: katero vrsto govora gojijo učenci zadnjega triletja osnovne šole doma, s svojimi sokrajani (nevrstniki), pri urah drugih predmetov (torej ne pri urah slovenščine), s svojimi sošolci in $\mathrm{z}$ vrstniki, z drugimi zaposlenimi na šoli; kako obvladajo svoj krajevni govor in kakšen je njihov odnos do narečja, $v$ anketni vprašalnik je bil kot predvidevana in med mladostniki pogosto uporabljana socialnozvrstna modifikacija vključen tudi sleng. Iz tega so izhajale raziskovalne hipoteze, npr. učenci doma najpogosteje govorijo krajevni narečni govor; s sokrajani (nevrstniki) govorijo predvsem narečno, s sokrajani (vrstniki) govorijo predvsem narečno, pri urah slovenščine najpogosteje govorijo knjižno, pri urah drugih predmetov najpogosteje govorijo nadnarečno obliko govora, ki vsebuje malo narečnih besed in več takih, ki jih uporabljajo na nacionalnem radiu in televiziji (vprašanje že samo nakazuje povezavo nacionalnih medijev s knjižnim jezikom, čeprav to ni več vedno tako), $s$ svojimi sošolci in z vrstniki najpogosteje govorijo v slengu itd. Pridobivanje podatkov je potekalo najprej s sestavo anketnih vprašalnikov, sledili sta kvalitativna in kvantitativna obdelava. Rezultati so pokazali (Interpretacija rezultatov), da je bilo od devetih hipotez, ki sta si jih zastavili avtorici monografije, potrjenih ( $\mathrm{v}$ celoti ali delno) kar sedem (učenci doma najpogosteje govorijo krajevni narečni govor; učenci s sokrajani (nevrstniki) govorijo predvsem narečno; učenci s sokrajani (vrstniki) govorijo predvsem narečno; pri urah slovenščine najpogosteje govorijo knjižno; učenci v šoli s svojimi sošolci in z vrstniki najpogosteje govorijo v slengu; učenci svoj krajevni govor obvladajo dobro; učenci imajo do svojega govora pozitiven odnos), ena se je potrdila le delno (učenci svoj krajevni govor obvladajo dobro - izkazalo se je namreč, da so učenci mnenja, da svoj krajevni govor obvladajo zelo dobro), dve pa se (na večini šol ali na nobeni šoli) nista potrdili (učenci $v$ šoli pri urah drugih predmetov najpogosteje govorijo nadnarečno obliko govora, ki vsebuje malo narečnih besed in več takih, ki jih uporabljajo na nacionalnem radiu in televiziji - izkazalo se je namreč, da se ob rabi malo narečnih besed in več takih, ki jih uporabljajo na nacionalnem radiu in televiziji, kaže težnja $\mathrm{k}$ rabi knjižnega jezika; učenci z drugimi zaposlenimi na šoli najpogosteje govorijo $\mathrm{v}$ nadnarečni obliki govora, ki je blizu krajevnemu narečnemu govoru - izkazalo se je namreč, da se povsod kaže težnja $\mathrm{k}$ rabi knjižnega jezika).

Avtorici na osnovi aktualnih teoretičnih ugotovitev in obsežnih ugotovitev, izhajajočih iz empiričnih raziskav (predvsem lastnih, potrjenih še s širšim naborom) uspešno kažeta na eni strani, (a) da avtorji učbeniških gradiv dosledno opozarjajo na pomembnost izbire okoliščinam ustrezne/primerne socialne zvrsti slovenskega jezika in jo tako uzaveščajo, na drugi (b) da le z dobrim znanjem jezika lahko narečno (»slovensko«) postavi most od narečnega/pogovornega do knjižnega.

$\mathrm{V}$ času, polnem številnih razprav o globalizaciji, internacionalizaciji $\mathrm{v}$ (visokem) šolstvu in vstopu angleščine 
(zaenkrat res (le) v visokem šolstvu) skozi glavni vhod, je monografija dobrodošla tudi kot razmislek o tem, da je (skoraj) vsak slovenski govorec dvojezičen - narečno in knjižno. Le znanje obojega pripomore k izražanju vsega: a) misli, čustev itd. ter b) strokovnega in znanstvenega. »Slovenščina« namreč zmore in zna, če le govorec hoče in zna.

\section{Alenka Valh Lopert}

Filozofska fakulteta Univerze v Mariboru alenka.valh@um.si

\section{VELIMIR PIŠKOREC UZ} SURADNJU SANJE JANKOVIĆ: TOMO MARETIĆ NA RASKRIŽJU FILOLOGIJE I JEZIČNE

POLITIKE. Zagreb: Udruga zagrebačkih esperantista, 2015., 116 str.

Monografija naslova Tomo Maretić na raskrižju filologije i jezične politike (2015.) najnovija je monografija Velimira Piškorca (1966.), redovitog profesora pri Katedri za njemački jezik Odsjeka za germanistiku Filozofskoga fakulteta Sveučilišta u Zagrebu i voditelja Poslijediplomskoga doktorskoga studija lingvistike na istome fakultetu. Tije- kom svoje gotovo dva i pol desetljeća duge znanstvene karijere, Piškorec je na temelju svojih radova uspio pokazati široko polje međusobno povezanih znanstvenih interesa kao što su dodirno jezikoslovlje s posebnim osvrtom na hrvatsko-njemačko/austrijske jezične i kulturne veze, istraživanje posuđenica, jezična biografistika, interlingvistika i esperantologija, dijalektna geografija i ekolingvistika itd., pri čemu je ostvario opsežnu bibliografiju koja obuhvaća čak 150 -ak jedinica. U tom zavidnom opusu osim brojnih znanstvenih studija, članaka, prikaza, prijevoda, televizijskih i radijskih priloga, znanstveno-stručnih zbornika, nalaze se i tri znanstvene monografije koje se pretežito bave dodirnim jezikoslovljem, hrvatsko-njemačko/ austrijskim jezičnim i kulturnim vezama te hrvatskokajkavskom književnošću pod nazivom Deutsches Lehngut in der kajkavisch-kroatischen Mundart von Đurđevec in Kroatien (1997.), Germanizmi u govorima đurđevečke Podravine (2005.) i Georgiana. Rasprave i ogledi o đurđevečkom govoru i hrvatskokajkavskoj književnosti (2005.), a u ovoj, četvrtoj po redu, monografiji, u suradnji sa Sanjom Janković, Piškorec se na primjeru Tome Maretića bavi interlingvistikom, znanstvenom disciplinom koja je u hrvatskim znanstvenim krugovima podosta zanemarivana. ${ }^{1}$

${ }^{1}$ U svakom slučaju, autor je dao svoj obol povijesti hrvatske interlingvistike (naročito esperantologije) objavivši sljedeće znanstvene radove: Terminologische und onomasiologische Aspekte des Spelin. 2012. Interlinguistische Informationen, Beiheft 19: 69-103.; Kroatische Esperanto-Lehrbücher. Autoren, Methoden, Werke. 2011. U: Florilegium Interlinguisticum. Festschrift für Detlev Blanke zum 70. Geburtstag, (ur.) Cyril Brosch i Sabine Fiedler. Frankfurt am Main: Peter Lang, 297-334.; Von Volapük zu Spelin. Zum Leben und Werk des kroatischen Plansprachlers Juraj (Georg) Bauer (1848-1900). 2010. Interlinguistische Informationen, Beiheft 17: 99-131.; Iz života i djela Mavra Špicera (1862. - 1936.). 2007. Našički zbornik 8: 145-210.; Naĝu, naĝu, ŝipo mia - prvi hrvatski esperantski časopis »Kroata Esperantisto« (1909. - 1911.). 2006. U: Jezik i mediji - 1 jezik : više svjetova, (ur.) Jagoda Granić. Zagreb-Split: Hrvatsko društvo za primijenjenu lingvistiku, 563-574. 